\title{
Influence of the Sugarcane vinasse of the balance of charges in high weathered oxide soil of subtropical region in Brazil
}

Marco Aurélio Pessoa-De-Souza ${ }^{1}$, Gisele Carneiro da Silva Teixeira ${ }^{2}$, Danielle Silva Beltrão ${ }^{1}$, Edgar Muniz ${ }^{1}$, Danillo Barbosa de Moura ${ }^{1}$, Alfredo Borges De-Campos ${ }^{3}$

${ }^{1}$ Universidade Federal de Goiás - UFG, GO. ${ }^{2}$ Universidade Estadual de Goiás - UEG, GO. ${ }^{3}$ Universidade Estadual de Campinas - UNICAMP, SP. E-mail: gisele.carneiro@ueg.br

\begin{abstract}
Brazil is oneof the largest sugarcane producers around the world, however the effects concerning environment issues in soil are still no well described.Soilelectrochemical can provide important information about residues uses and environmental contamination, and thenzero point of charge (ZPC) is a parameter that may demonstrate this variation. In this study, It was analyzed thesoil behavior when submitted to sugarcane vinasse application in different doses simulating high and low doses application as regularly done by the manufactures in typical tropical weathered oxisols. To procedure ZPC test, microcosmsexperiment was managed with all parameters measured and controlled in a factorial design: 2 soil depths (superficial group $-0.0-20.0 \mathrm{~cm}$ and sub-superficial group $-60.0-80.0 \mathrm{~cm}), 3$ salt concentration $(0.002 ; 0.02$ and 0.2 $\mathrm{mL} \mathrm{NaCl}$ ), and 4vinasse doses (Without application; Low - $164.28 \mathrm{~mL} \mathrm{~L}^{-1}$; Intermediate $-328.57 \mathrm{~mL} \mathrm{~L}^{-1}$ and High $657.14 \mathrm{~mL} \mathrm{~L}^{-1}$ ), after incubation all the samples were measured electrochemically.Based on these analyses, data rised two main highlights: 1 . vinasse low doses behaved like a buffer solution, 2 . High doses in sub-superficial layer disturbed ZCP. Then, vinasse seems correlate with lixiviation capacity, and then over-applications can disrupt soil solution on this soil.
\end{abstract}

Keywords: electrochemical; residue; sugar-ethanol production; environmental impact.

\section{Influência da vinhaça no balanço de cargas em LATOSSOLO VERMELHO Distrófico da região subtropical do Brasil}

\section{Resumo}

O Brasil é um dos maiores produtores de cana-de-açúcar do mundo, porém os efeitos relativos às questões ambientais do uso dos resíduos desta atividade no solo ainda não estão bem descritos. A eletroquímica do solo pode fornecer informações importantes sobre o impacto do uso de resíduos e contaminação ambiental, sendo o ponto de carga zero (ZPC) um parâmetro que pode demonstrar esta variação. Neste estudo, foi analisada a resposta do solo quando submetido à aplicação de vinhaça de cana-de-açúcar em diferentes doses, utilizando a aplicação de altas e baixas doses deste resíduo normalmente feita pelas indústrias sucroalcooleira em Latossolos tropicais intemperizados típicos. Para o teste de ZPC, o experimento laboratorial foi realizado com todos os parâmetros medidos e controlados em um planejamento fatorial: 2 profundidades de solo (grupo superficial - 0,0-20,0 cm e grupo subsuperficial $60,0-80,0 \mathrm{~cm}$ ), 3 concentração de solução salina $(0,002 ; 0,02$ e 0,2 $\mathrm{mL} \mathrm{NaCl}$ ) e 4 doses de vinhaça (Sem aplicação; Baixa - 164,28 mL L'-1 Intermediário - 328,57 $\mathrm{mL} \mathrm{L}^{-1}$ e Alta $657,14 \mathrm{~mL} \mathrm{~L}^{-1}$ ), após a incubação todas as amostras foram medidas eletroquimicamente e calculado o ZPC. Com base nessas análises, observou-se: 1. A dose mais baixa de vinhaça apresentou-se como uma solução tampão, 2 . As doses altas na camada subsuperficial influenciaram a ZPC. Assim, a vinhaça parece estar correlacionada com a capacidade de lixiviação, desta forma, aplicações de altas doses de vinhaça nestes solos podem afetar eletronicamente a solução dos mesmos.

Palavras-chave: eletroquímica; resíduo; produção sucroalcooleira; impacto ambiental. 


\section{Introduction}

Sugarcane vinasse is a liquid residue coming fromhigh sugar-ethanol production(LOPESet al., 2016; NASPOLINlet al., 2017). This supply chain is associated with the of sugarcane production, which in Brazil has been growing territorially, especially in subtropical regions, as Cerrado Biome. Generally, agriculture development without logistic planning turns to environmental problems, as residue disposals(MATEO-SAGASTA; BURKE, 2012). Its common soil to become final destionation in nature(CHRISTOFOLETTI et al., 2013), because it can be freely used, and due its capacity to degrade residues(LEHMANet al., 2015; LOURENCETTlet al., 2012), promoted by microorganisms of soils(LEHMANet al., 2015).

Vinassehas an heterogeneous content, and it iss dependent of the seasonal weather. Despite of that, vinasse is usually rich in potassium, calcium, magnesium and, mainly organic matter, and thus, it has different types of charges in the mixture (STONE, 2014). In this way, all the recommendation of vinasse in doses is basedon its chemical composition. So, the excesses cases may run into some negative environmental events(BRAGAet al., 2017; CARVALHOet al., 2017; CHRISTOFOLETTlet al., 2013), for exemple withZPC (Zero of Point Charge) of soils changes(RAIJ, 1973; SAKURAlet al., 1989).

Despite several studies focused on vinasse behavior in soils, this study intent demonstrates how critical it can be an irregular application on fragile soils, like ones founded in subtropical conditions. More than that, vinasse may be useful when the soils are well described physically and chemicallybecause of those specificities it is possible to predict the soil effect over the inputs. Despite the regular use, this specific question was not already noticed considering just the soil solution, moreover on deep layers.

This study is proposing to clarify how vinasse applications may change the solution of highly weathered soils, like oxisols. These types of soils have a high capacity of sorption, so high potential to be a sort of environmental fate. This study did not intend to make a management approach for crop production but differently is focused on indicating what kind of problems are brought when the irregular use of vinasse without taking into account the factors related to the chemical restrictions of the soil.

Oxisol class is the typical soil occurrence in subtropical climate(according toAmerican Classification Soil Taxonomy reference), in Brazil this type of soil is known by latossolo (Latosol suggested translation by Muniz et al. (2011).These soils are formed under significant weathering-leaching conditions(Shamshuddin, 2001), with a residual concentration of mineral with $\mathrm{pH}$ dependence(BOLLAND, 1980) and as main representatives are kaolinite, gibbsite, and iron- and aluminum- oxides(MIRANDATREVINO;COLES, 2003; SOUZAet al., 2017).

Due to this specifically clays in its constitution, and the level of weathering-leaching conditions and use, the soil solution chemical composition may change the global liquid surface charge(BERGAYA; LAGALY, 2013). This type of clay may assume different chemical character as positive or negative liquid charge(SHAMSHUDDIN, 2001), and that characteristic is known chemically in Brazilian Soil Classification System as acric(positive soil surface charges) and dystrophic and/or eutrophic (negative soil surface charges) conditions (EMBRAPA, 2018).

Much more weathering-leaching is the soil, more positive charges it has on its surface(BLEAM; BLEAM, 2017), and in this way, it may interact with negative charges of polar molecules present in thesoil solution.All types of clay minerals have a $\mathrm{pH}$ point or range whose liquid charge acquires nullity, in which both positive and negative charges are similar on the soil surface(APPELet al., 2003; RAIJ, 1973; SAKURAlet al., 1989).

Therefore, some products used in agriculture, due to their chemical characteristics and conditionscanimpose a change of this point or even range(SANTOSet al., 2017; TEDESCOet al., 2011), and this study had structured thatvinasse sugarcane may be one of these inputs. So, this present research aimed todemonstrate the changes that sugarcane vinassedoses impose on the zero point of charge, as a pollution problem, in the oxide soil surface and deep-surfaceof subtropical climate. 


\section{Materials and Methods Soil Characterization}

The soil selected was the most representative ofCerrado Biome, Midwest, Goiás, Brazil, and classified by Embrapa(2018) as LATOSSOLO VERMELHO Distrófico. The soil was collected at Agronomy School, Federal University of Goiás, Brazil, in the remainingarea,therefore, it never had the previous contact with agricultural inputs.

Two depths were collected: 0-20 and 60$80 \mathrm{~cm}$, due to the high leaching capacity of the sugarcane vinasse.Then, chemical and mineralogical analyses were performed to qualify the type of soil (Table 1 ).

\section{Sugarcane vinasse composition}

Vinasse used in this study came from a first-generation ethanol plant (1g ethanol from fermentation of sugarcane juice), coming from the sugar and alcohol industry located in the Midwest of Brazil (Goianésia city, State Goiás). It was collected a blend of $10 \mathrm{~L}$ of sugarcane vinasseat room temperature. The samples were refrigerated until proceeding to chemical analysis (Table 2), following APHA/AWWA/WEF (2012).

\section{Experimental Design}

The microcosmic control study was performed with factorial design (4 vinasse doses X 3 electrolytic solutions $X 8$ repetitions) as proposed by Ankomah (1991) and Raij (1973). This microcosms experiment was fulfilled with $6.67 \mathrm{~g}$ of soil $(<2.0 \mathrm{~mm}$ of air-dried fine soil) into falcon $50 \mathrm{~mL}$ conical centrifuge tubes. Soil samples were saturated until $60 \%$ of the field capacity humidity, and in the sequence $2.8 \mathrm{~mL}$ of the vinasse. Soil mass was calculated based on $4 \mathrm{~g}$ of soil $(<2.0 \mathrm{~mm}$ of air-dried fine soil) after vinasse application to proceed further ZPC determination.

It was used four different doses of vinasse: 0 (control treatment - exclusively ultrapurewater), $157.12 ; 314.25$ and $628.5 \mathrm{~mL} \mathrm{~L}^{-1}$, incubated by 72 hours. After this, the samples were centrifuged, dried and sieved to granulometry $<2.0 \mathrm{~mm}$. At this point, samples were ready for ZPC determination, as recommended by Raij (1973), to tropical soils.

\section{Zero Point of Charge (ZPC) Analysis}

This determination was executed followingAnkomah (1991) and Raij (1973)by electrochemistry methods. The measureis taken by sorbed $\mathrm{H}^{+}$and $\mathrm{OH}^{-}$determination, treated with any vinasse concentration, considering soil $\mathrm{pH}$, of eight (08) acid-base titration with $10 \mathrm{~mL}$ each of electrolytic solution. Among the solutions were used $\mathrm{HCl} 0.2 \mathrm{molL}^{-1}, \mathrm{NaOH} 0.2 \mathrm{molL}^{-1}$ and three NaCldifferent concentrations: $0.002,0.02$ and 0.2 $\mathrm{molL}^{-1}$, to basic solutions. To the acid solution was used four (04) different volumes $(0.5,1.0,2.0$ and $3.0 \mathrm{~mL}$ ) and to a basic solution was added three (03) different volumes (0.5, 1.0 and $2.0 \mathrm{~mL}$ ), for the seven (07) samples, and the last one, without any application of an acid-base solution. All the samples were completed to $20 \mathrm{~mL}$ with ultra-pure water. A black prove was conducted just with the solutions, without soils samples, that were used in the equation proposed by Ankomah (1991), Raij (1973) and Sakurai et al.(1989).

As proposed by Raij (1973) this study is considered a qualitative analysis, and is aimed to present the variation on the natural electrochemical conditions. That said, the equation results were plotted, basing on $\mathrm{pH}$ soil, and the inflection point in the curve was described as ZPC point, to each vinasse concentration.

\section{Results}

Results were grouped by depth: $A-D$ to 0-20 cm (superficial group) and $\mathrm{E}-\mathrm{H}$ to $60-80 \mathrm{~cm}$ (sub-superficial group). That division by group wassuggested to the better observation ofvinasse effects on electrochemical terms (Fig. 1). According Table 1, the first group $(0-20 \mathrm{~cm})$ had low point of nullity $(\mathrm{pH}=3.4)$ charge when compared to the second group $(60-80 \mathrm{~cm})(\mathrm{pH}=$ 6.0). Still, surface samples havemore permanent negative charge $\left(\sigma_{0}=8.4 \mathrm{mmolc} \cdot \mathrm{kg}^{-1}\right)$ then subsurface samples $\left(\sigma_{0}=1.3 \mathrm{mmolc} \cdot \mathrm{kg}^{-1}\right)$, but the same prominent behavior had to be seen between these two depths $\left(\sigma_{H}=32.3 \mathrm{mmolc} \cdot \mathrm{kg}^{-}\right.$ ${ }^{1}$ to surface group and $\sigma_{H}=18.4 \mathrm{mmolc} \cdot \mathrm{kg}^{-1}$ to sub-surface group). All this data showed in Table 1.

Sugarcane vinasse is considered an acid solution $(\mathrm{pH}=4.1$ ) (Table 2 ). Also, the most expressive nutrients were Calcium, Potassium, Sulfur, and Nitrogen $(0.55,0.41,0.35$ and 0.20 -all them in \%-, respectively), and Organic Matter with $3.11 \%$ of all the solution.

To the superficial group, vinasse control (Fig. 1-A) showed ZPC around 4.9, this soil presents in its surface, positive charges (Table 1 ), and, in this way, get more easily anions exchange 
capacity. This control treatment has the same performance to all three different saline solutions, and like this, it reveals the buffer capacity of this type of soil (high weathered oxide soil) and shows that $\mathrm{pH}$ point (4.9), liquid charge acquires nullity. Low and intermediate vinasse doses, (Fig. 1-B) and (Fig. 1-C), respectively, demonstrated a similar increase in the $\mathrm{pH}$ range, where the setpoint was around 6.0, which indicatesimmediate effects in the soil solution.

High concentration (Fig. 1-D) points to an increase of the $\mathrm{pH}$ range next to neutrality (slightly acidic - 6.6), two logs above indicated by control treatment (Fig. 1-A), and a clear demonstration of ZPC alteration.

To sub-superficial group $(60-80 \mathrm{~cm})$ was observed generally similar behavior when pairwise to the superficial group $(0-20 \mathrm{~cm})$, although control samples (Fig. 1-E) had less acidic $\mathrm{pH}$ when compared to superficial control samples (Fig. 1-A). This different $\mathrm{pH}$ behavior attenuates the effects of the sugarcane vinasse on $\mathrm{pH}$ range variation (minor $\Delta$ Log).As vinasse doses increased, ZPC also increased the position in the $\mathrm{pH}$ range, as confirmed by Fig 1 ( $\mathrm{F}, \mathrm{G}$, and $\mathrm{H})$.

All treatments, among saline solutions, were observed a buffer behavior, identified by curves similarity behavior, except to subsuperficial depth, high dose and high concentration (Fig. 1-H).

\section{Discussion}

The zero point of charge as the $\mathrm{pH}$ value of a solution in equilibrium is determined by net charge from oxides. The ZPC of oxides serves as a convenient reference for predicting how the surface charge and potential on oxides depend on $\mathrm{pH}$.Some studies are proved positive(JIANGet al., 2012) and negative (CARDINet al., 2016) effect of vinasse in different types of soils.

The data showed a clear effect of vinasse application in both depths, especially in 60-80 with the top dose. Excess of surface charges is one of the major factors affecting clays dispersion. In this case, $\mathrm{Ca}^{2+}, \mathrm{Mg}^{2+}, \mathrm{K}^{+}$, and $\mathrm{Na}^{+}$ interact with surface charges and the flocculation alter andimprove the $\mathrm{pH}$ balance in the soil solution. Meloet al. (2016) founded similar results with excess charges formation and changes in $\Delta \mathrm{pH}$ measures to sandy soils, more than clayey soil. The authors commented the reason was the smaller buffering capacity of the sandy soils, caused by the granulometric difference.
When the $\mathrm{pH}$ gets closer to the isoelectric point of particles, the charge is reduced(MELO et al., 2016), and this phenomenon may be explained by the excess of surface charge, that is one of the major factor affecting clay dispersion (RIBEIRO et al., 2012; MELOet al., 2016; CABRAL FILHO et al., 2019).AccordingtoRibeiro et al.(2012),vinasse applied in Latosols were not altered the zeta potential in the first $10 \mathrm{~cm}$.

Thus, pH solution becamecloserto neutrality conditions and the authorsshowed that behavior had a relation with cation and anion exchange capacity. To Cabral Filho et al. (2019), a more specifically high concentration of basiccations in the vinasse composition may alter that exchange capacity. Thus, this study aims to prove that a high concentration of vinasse in-depth, infer to buffer behavior.Because the lower number of negative charges demands less amount of cations to balance them, resulting in a thinner electric double layer. Therefore, for this reason, the curve of figure $1-\mathrm{H}$ presents a sinusoidal form, since the number of free cations is much higher than the capacity of interaction with binding sites.

Vinasse, as a strong acid solution, may express that property in soil solution by excess and became inappropriate physical-chemical soil conditions to agricultural production. Acid soil conditions hamperthe availabilityof essential nutrients to crop production and decrease productivity (FONTES; ALLEONI, 2006).On the other hand, it is important to make it clear that this study does not intend to generalize this result to all types of oxisol. This study demonstrates a trend based on a parameter (ZPC), also chemical changes may happen, and these, in turn, can have a negative impact on the environment.

\section{Conclusion}

Excessive dose of sugarcane vinasse alter ZPC point in high weathered soil in sub-tropical regionsdue to the high amount of ions that can interact with the binding sites of the soils rich in oxides.This phenomenon can be observed more closely in deeper parts of the soil, mainlydue to the capability of vinasse leaching. Furthermore, sugarcane vinasse induces environmental impact in-depth on Latosols from subtropical regions.

\section{References}

ANKOMAH, A.B. Filtration-rate technique for determining zero point of charge of iron 
oxides.Clays and Clay Minerals, v.39, p.100-102, 1991.https://doi.org/10.1346/CCMN.1991.03901 $\underline{13}$

APHA/AWWA/WEF.Standard methods for the examination of water and wastewater.Standard Methods, v. 541, 2012.

APPEL, C.; MA, L.Q.; RHUE, R.D.; KENNELLEY, E. Point of zero charge determination in soils and minerals via traditional methods and detection of electroacoustic mobility. Geoderma, v.113, p.7793, 2003. https://doi.org/10.1016/S00167061(02)00316-6

BERGAYA, F.; LAGALY, G. General introduction: clays, clay minerals, and clay science. 2. ed. Developments in Clay Science. Elsevier, 2013.https://doi.org/10.1016/B978-0-08-0982588.00001-8

BLEAM, W.; BLEAM, W. Clay mineralogy and chemistry, soil and environmental chemistry.Chapter

3 ,

2017.https://doi.org/10.1016/B978-0-12-8041789.00003-3

BOLLAND, M.D.A. pH-independent and $\mathrm{pH}$ dependent surface charges on kaolinite. Clays and Clay Minerals, v.28, p.412-418, 1980.

https://doi.org/10.1346/CCMN.1980.0280602

BRAGA, L.P.P.; ALVES, R.F.; DELLIAS, M.T.F.; NAVARRETE, A.A.; BASSO, T.O.; TSAI, S.M.Vinassefertirrigation alters soil resistome dynamics: an analysis based on metagenomic profiles. Bio Data Mining, v.10, p.1-7, 2017.

https://doi.org/10.1186/s13040-017-0138-4

CABRAL FILHO, F.R.; VIEIRA, G.D.S.; SILVA, N.F.; CUNHA, E.S.; SANTOS, L.N.S.; RODRIGUES, C.R.; CUNHA, F.N.; TEIXEIRA, M.B.; SOARES, F.A.L. Sugarcanevinassecations dynamics in cerrado soils, Brazil. Sugar Tech, v.21, p. 38-46, 2019. https://doi.org/10.1007/s12355-018-0620-4

CARDIN, C. A.; SANTOS, C. H.; ESCARMÍNIO, M. A.Impacts of vinasse and methods of sugarcane harvesting on the availability of $\mathrm{K}$ and carbon stock of an Argisol. Revista Ceres, v.63, p.95-102, 2016. https://doi.org/10.1590/0034737X201663010013
CARVALHO, J.L.N.; NOGUEIROL, R.C.; MENANDRO, L.M.S.; BORDONAL, R.O.; BORGES, C.D.; CANTARELLA, H.; FRANCO, H.C.J. Agronomicandenvironmentalimplicationsofsugar canestrawremoval: a majorreview. GCB Bioenergy, v.9, p.1181-1195, 2017. https://doi.org/10.1111/gcbb.12410

CHRISTOFOLETTI, C.A.; ESCHER, J.P.; CORREIA, J.E.; MARINHO, J.F.U.; FONTANETTI, C.S.Sugarcane vinasse: Environmental implications of its use. Waste Management, v.33, p. 2752-2761, 2013. https://doi.org/10.1016/j.wasman.2013.09.005

MELO, T.R.; TELLES, T.S.; MACHADO, W.S.; FILHO, J.T. Factors affecting clay dispersion in Oxisols treated with vinasse. Semina:Ciências Agrárias, v.37, p.3997-4004, 2016. https://doi.org/10.5433/1679$\underline{0359.2016 v 37 n 6 p 3997}$

EMBRAPA. Centro Nacional de Pesquisa de Solos. Sistemabrasileiro de classificação de solos. 5.ed. Brasília: Embrapa, 2018. 355p.

FONTES, M.P.F.; ALLEONI, L.R.F. Electrochemical attributes and availability of nutrients, toxic elements, and heavy metals in tropical soils.ScientiaAgricola, v.63, p. 589-608, 2006. https://doi.org/10.1590/S0103$\underline{90162006000600014}$

JIANG, Z.P.; LI, Y.R.; WEI, G.P.; LIAO, Q.; SU, T.M.; MENG, Y.C.; ZHANG, H.Y.; LU, C.Y. Effect of longterm vinasse application on physico-chemical properties of sugarcane field soils. Sugar Tech, v.14, p.412-417, 2012.

https://doi.org/10.1007/s12355-012-0174-9

LEHMAN, R.M.; CAMBARDELLA, C.A.; STOTT, D.E.; ACOSTA-MARTINEZ, V.; MANTER, D.K.; BUYER, J.S.; MAUL, J.E.; SMITH, J.L.; COLLINS, H.P.; HALVORSON, J.J.; KREMER, R.J.; LUNDGREN, J.G.; DUCEY, T.F.; JIN, V.L.; KARLEN, D.L. Understanding and enhancing soil biological health: The solution for reversing soil degradation. Sustainability, v.7, p. 988-1027, 2015.https://doi.org/10.3390/su7010988

LOPES, M.L.; PAULILLO, S.C.L.; GODOY, A.; CHERUBIN, R.A.; LORENZI, M.S.; GIOMETTI, F.H.C.; BERNARDINO, C.D.; AMORIM NETO, H.B.; AMORIM, H.V. Ethanol production in Brazil: a 
bridge between science and industry. Brazilian Journal of Microbiology,v.47, p. 64-76, 2016. https://doi.org/10.1016/j.bjm.2016.10.003

LOURENCETTI, C.; MARCHI, M.R.R.; RIBEIRO, M.L. Influence of sugar cane vinasse on the sorption and degradation of herbicides in soil under controlled conditions. Journal of Environmental Science and Health - Part B Pesticides, Food Contaminants, and Agricultural Wastes, v.47, p. 949-958,2012.

https://doi.org/10.1080/03601234.2012.706562

MATEO-SAGASTA, J.; BURKE, J. Agriculture and water quality interactions: a global overview.Roma: FAO. 2012.

MIRANDA-TREVINO, J.C.; COLES, C.A. Kaolinite properties, structure and influence of metal retention on pH.Applied Clay Science, v.23, p. 133-139, 2003. https://doi.org/10.1016/S01691317(03)00095-4

https://doi.org/10.1016/S0169-1317(03)00095-4

MUNIZ, M.; CURI, N.; SPAROVEK, G.; CARVALHO FILHO, A.; SILVA, S.H.G.Updated brazilian'sgeoreferenced soil database: an improvement for international scientific information exchanging. In: Principles, Application and Assessment in Soil Science. 2011.

https://doi.org/10.5772/29627

NASPOLINI, B.F.; MACHADO, A.C.O.; CRAVO, W.B.; FREIRE, D.M.G.; CAMMAROTA, M.C. Bioconversion of sugarcane vinasse into highAdded value products and energy. BioMed Research International, 2017. https://doi.org/10.1155/2017/8986165

RAIJ, B. Determinação do ponto de carga zero em solos. Bragantia, v.32, p. 337-347, 1973. https://doi.org/10.1590/S0006$\underline{87051973000100018}$
RIBEIRO, B.T.; LIMA, J.M.; CURI, N.; OLIVEIRA, G.C. Electrochemicalattributesofsoilsinfluencedbysuga rcanevinasse. BioscienceJournal, v.28, p.25-32, 2012.

SAKURAI, K.; OHDATE, Y.; KYUMA, K.Factors affecting zero point of charge (zpc) of variable charge soils.Soil Science and Plant Nutrition, v.35, p.21-31, 1989. https://doi.org/10.1080/00380768.1989.1043473 $\underline{3}$

SANTOS, S.R.; RIBEIRO, D.P.; MATOS, A.T.; KONDO, M.K.; ARAÚJO, E.D. Changes in soil chemical properties promted by fertigation with treated sanitary wastewater. Journal of Brazilian Association of Agricultural Engineering, v.37, p.343-352, 2017.https://doi.org/10.1590/18094430-eng.agric.v37n2p343-352/2017

SHAMSHUDDIN, J. The charge properties of highly weathered tropical soils.Geological Society of Malaysia Annual Geological Conference, v.2-3, p.527-259, 2001.

SOUZA, M.A.P.; CAMYLLA, P.; ASSIS, R.; HENRIQUE, F.; SALGADO, M.; GOMES, L.; BORGES, A.; ANUNCIAÇÃO, C.E.; NEVES, A.; MOREIRA, H.; PAULA, E. Poorly crystalline Fe ( III ) oxide excess can to alter the electrochemical paths of hydromorphic soil in the Palm Swampy Vegetation. Multi-Science Journal, v.9, p.7-10, 2017.

https://doi.org/10.33837/msj.v1i9.370

STONE, M. Formal recommendation from: national organic standards board (nosb) to: the National Organic Program (NOP). 2014.

TEDESCO, M.J.; LAUSCHNER, M.H.; GIANELLO, C.; BORTOLON, L.; KRAY, C.H. Land disposal potential of tobacco processing residues. Ciência Rural, v.41, p. 236-241, 2011.https://doi.org/10.1590/S0103$\underline{84782011005000002}$ 


\section{Tables}

Table 1. Chemical and mineralogical attributes of the Acrudox from subtropical region

\begin{tabular}{|c|c|c|c|c|c|c|c|c|c|c|c|c|c|}
\hline \multirow{2}{*}{$\begin{array}{l}\text { Depth } \\
(\mathrm{cm})\end{array}$} & \multirow{2}{*}{ NSPE } & \multirow{2}{*}{$\begin{array}{c}\mathrm{pH} \\
\mathrm{CaCl}_{2}\end{array}$} & \multirow{2}{*}{$\Delta \mathrm{pH}$} & \multirow{2}{*}{$\mathrm{K}_{\mathrm{i}}$} & $\underline{\sigma_{0}}$ & $\sigma_{\mathrm{H}}$ & CEC & CR & $C$ & Clay & $\mathrm{Kt}$ & $\mathrm{Fe}$ & $\mathrm{Al}$ \\
\hline & & & & & \multicolumn{4}{|c|}{$\mathrm{mmol}_{\mathrm{c}} \mathrm{kg}^{-1}$} & \multicolumn{5}{|c|}{$\mathrm{g} \mathrm{kg}^{-1}$} \\
\hline $0-20$ & 3.4 & 4.3 & $(-) 0.5$ & 0.78 & 8.4 & 32.3 & 43 & 38 & 16 & 350 & 248 & 59 & 113 \\
\hline $60-80$ & 6.0 & 5.3 & $(+) 0.6$ & 0.79 & 1.3 & 18.4 & 14 & 7 & 6 & 450 & 196 & 134 & 172 \\
\hline
\end{tabular}

NSPE: null saline point effect: $\mathrm{pH}$ point corresponding to potentiometric titration curve intersection in $\mathrm{KCl}$ solution; $\Delta \mathrm{pH}=\mathrm{pH} \mathrm{KCl} 1 \mathrm{M}-\mathrm{pH} \mathrm{H} \mathrm{H}_{2} ; \sigma_{0}=$ permanent negative charge; $\sigma_{\mathrm{H}}=$ variable negative charge; $\mathrm{CEC}=$ Cation Exchange Capacity; $\mathrm{CR}=$ Cation Retention; $\mathrm{C}=$ Organic Carbon; $\mathrm{Kt}=$ Kaolinite; $\mathrm{Fe}=$ Iron Oxide; $\mathrm{Al}=$ Alunminium oxide

Table 2. Sugarcane vinasse chemical composition

\begin{tabular}{llllll}
\hline $\mathrm{N}$ & $\%$ & 0.20 & $\mathrm{Mo}$ & $\%$ & 0.0002 \\
Total P $\left(\mathrm{P}_{2} \mathrm{O}_{5}\right)$ & $\%$ & 0.0075 & $\mathrm{Al}$ & $\%$ & 0.0050 \\
$\mathrm{~K}\left(\mathrm{~K}_{2} \mathrm{O}\right)$ & $\%$ & 0.41 & $\mathrm{Ba}$ & $\%$ & 0.0054 \\
$\mathrm{Ca}$ & $\%$ & 0.55 & $\mathrm{Cd}$ & $\%$ & 0.016 \\
$\mathrm{Mg}$ & $\%$ & 0.032 & $\mathrm{Cr}$ & $\%$ & 0.0015 \\
$\mathrm{~S}$ & $\%$ & 0.35 & $\mathrm{Ni}$ & $\%$ & 0.002 \\
$\mathrm{Fe}$ & $\%$ & 0.0087 & $\mathrm{~Pb}$ & $\%$ & $\mathrm{Nd}$ \\
$\mathrm{Mn}$ & $\%$ & 0.00075 & Organic matter & $\%$ & 3.11 \\
$\mathrm{Cu}$ & $\%$ & $\mathrm{nd}$ & $\mathrm{C} / \mathrm{N}$ ratio & & 9.89 \\
$\mathrm{Zn}$ & $\%$ & 0.0005 & Density & $\mathrm{g} \mathrm{mL}^{-1}$ & 1.00 \\
$\mathrm{~B}$ & $\%$ & 0.0015 & $\mathrm{pH}$ & & 4.1 \\
$\mathrm{Na}$ & $\%$ & 0.011 & Eh & $\mathrm{mV}^{-1}$ & 260 \\
$\mathrm{Co}$ & $\%$ & $\mathrm{nd}$ & Conductivity & $\mathrm{mS} \mathrm{cm}^{-1}$ & 8.52 \\
\hline
\end{tabular}

nd - not detected 


\section{Figures}

Figure 1.Potentiometric titration curve of the Acrudox (Latosol/Latossolo) in Subtropical Region. A - D representing surface samples group $(0-20 \mathrm{~cm})$ and $\mathrm{E}-\mathrm{H}$ representing subsurface samples group $(60-80 \mathrm{~cm})$. Each group has four conditions to vinasse dose $(0-$ control, 164.28 - low dose, 328.57 - intermediate dose and 657.14 - high dose, all in $\mathrm{mL} \cdot \mathrm{L}^{-1}$ ), and each condition has three saline solution concentration (0.002 - low concentration, 0.02 intermediate concentration and 0.2 - high concentration, all in $\mathrm{mol} \cdot \mathrm{L}^{-1}$ )
